\title{
Responsibilities distribution between different levels of government for public services delivery in EU countries
}

\author{
Emil Mutafov ${ }^{1 *}$ \\ ${ }^{1}$ Department of Regional Development, Faculty of Economics, Trakia University, Stara Zagora, \\ Bulgaria
}

\begin{abstract}
The main goal of the article is to review and analyze the pros and cons when public services are provided by different levels of government in EU countries. Methods such as analysis and synthesis, comparative method, mathematical and statistical are used for achieving the goal. The results will clarify the distribution of responsibilities for public services delivery in EU countries, which seek to fully cover the principle of subsidiarity stated in the European Charter of Local Self-Government. Transferring more powers will lead to new responsibilities to local government and it needs to be more effective, as larger municipalities would be able to fit in faster and better. The conclusions are related to the more efficient and effective distribution of public services between different levels of government.
\end{abstract}

\section{Importance of public services}

Fairness in the distribution of responsibilities, resources and powers is very important and is often violated due to the lack of connection between the local community and its elected representatives in the local government. This leads to a lack of control from local government on its taxpayers and voters, which has a negative impact on the choice of appropriate services, setting local development priorities, the efficiency of the use of local public resources. Adequate national policy for creating a balance at each level of territorial governance for the purpose of more efficient functioning of public institutions is called decentralization of public government [6].

Public goods are the basis of the services provided and the benefit for each individual. This led to a closer look at public goods in search of their main characteristics.

Table 1. Main characteristics of private and public goods

\begin{tabular}{|c|c|}
\hline Private goods & Public goods \\
\hline $\begin{array}{c}\text { They are relatively easy to measure quantitatively } \\
\text { and qualitatively }\end{array}$ & $\begin{array}{c}\text { It is relatively difficult to measure } \\
\text { quantitatively and qualitatively }\end{array}$ \\
\hline
\end{tabular}

\footnotetext{
* Corresponding author: emil.mutafov@,trakia-uni.bg
} 


\begin{tabular}{|c|c|}
\hline They can be consumed / used / by one person & $\begin{array}{c}\text { They are used jointly and simultaneously } \\
\text { by many people }\end{array}$ \\
\hline It is easy to exclude someone who does not pay & $\begin{array}{l}\text { It is difficult to exclude someone who } \\
\text { does not pay }\end{array}$ \\
\hline The individual has a choice to use or not the good & $\begin{array}{l}\text { The individual has no choice to use or not } \\
\text { the good }\end{array}$ \\
\hline $\begin{array}{c}\text { The individual has a choice about the type and } \\
\text { quality of goods }\end{array}$ & $\begin{array}{l}\text { The individual has little or no choice } \\
\text { about the type and quality of goods }\end{array}$ \\
\hline $\begin{array}{l}\text { Payment for goods is directly related to the supply } \\
\text { and consumption }\end{array}$ & $\begin{array}{l}\text { Payment for goods is not directly related } \\
\text { to the supply and consumption }\end{array}$ \\
\hline $\begin{array}{c}\text { Distribution decisions are mainly the result of a } \\
\text { market mechanism }\end{array}$ & $\begin{array}{l}\text { Distribution decisions are mainly the } \\
\text { result of political processes }\end{array}$ \\
\hline
\end{tabular}

All goods that meet the characteristics of only one column can be defined as purely private or purely public goods. All goods that meet at least one characteristic of the two columns can be defined as mixed. Public goods and services are very often considered under one denominator, with an equivalent nature. In the literature, they are often found together "public goods and services" [8].

Given the distribution of public goods and services, each country chooses what its policy should be in their provision. For example, George Stigler, a professor at Columbia University, says that "there are a number of functions that are typically national because they are indivisible. The biggest is national defense ..... foreign policy, public administration and control of relations between lower levels of government. " [5]. On the other hand, who would provide and best provide the "cleanliness" service? Of course, the closest level of government to a household. The aim is to provide the highest quality and most accessible public services from the appropriate level of government.

Prominent economist and professor at the University of Maryland - Wallace Oates developing theorems for net loss of wealth if all public services are provided by the central government "For a public good - the consumption of which is intended for the whole population, but by geographical regions and where the costs of the central government are the same for all jurisdictions(municipalities), it will always be more efficient for the local government to supply Pareto-efficient quantities of goods, than the central government to deliver any equal quantity in all municipalities" [3]

\section{Distribution of public services between authorities and decentralization}

Depending on the structure and policy of a given country, it distributes the responsibilities for the various services between it and the lower level of government and delegates certain powers for providing public services. In order to obtain a positive result from the transfer of powers and responsibilities for improving the quality of public services, resources (financial, administrative, etc.), must be transferred in parallel to cover local government needs. In this way, a local structure will have everything necessary to improve the quality of the services it offers. The balanced transfer of powers and resources within each national policy takes place through the process of decentralization. In general, decentralization can be defined as a 
process of transferring powers and resources from higher to lower levels of public administration.

Depending on the focus and scope of the transfer of powers and resources, decentralization can be:

- Administrative - characterized with the distribution of powers in administration;

- Political - it aims to give more power to citizens and their more active participation in decision-making. Increasing the group of people involved in decision-making means a higher level of political decentralization;

- Market - this means the denial of public authorities to provide certain services on a competitive basis and prices from business;

- Financial - it's characterized by the transfer of resources and opportunities to gain more, as well as powers and responsibilities for financing public services [4].

When we talk about financial decentralization, the degree of independence of a local structure is determined by:

- The types of revenues and revenue powers over the resources entering the budget at the lower level of government;

- Expenditure rights and responsibilities at the lower level of government and the possibility of their use.

The policy of financial decentralization must also comply with certain principles such as: equality between the benefits of public services and ensuring a minimum volume of public services determined by national standards.

In reality, we cannot decentralize everything, because there are services that would be inefficient and unfair if they were provided by the lower level of government. A balance is needed in the distribution of services, resources for their production and decision-making powers. The most important is to have balance between responsibilities and financial and management powers because no institution can be required to perform certain tasks without being given management and control powers [2].

According to Dr. George Benson, decentralized governments have some major advantages such as:

- Prevention of unjustified concentration of managerial power, which may be dangerous for freedom;

- Providing greater opportunities for political training through practice in state and local government; $[1]$.

Allowing greater adaptation of national policies to the needs of individual territorial areas

\section{Levels of sub-national governance of EU countries}

Before analyzing the structure and scope of public services in the countries of the European Union, it is necessary to review by country, how many and what levels of government are available. The purpose of this division is to make it easier to differentiate responsibilities at each level of government.

In the European Union there are three countries with a federal structure - Germany, Austria, and Belgium, one has an almost federal structure - Spain, and the rest can be defined as unitary states. Although formally unitary, these 23 countries have different territorial structures. In Portugal and Finland, there are separate regions in only a part of the national territory (autonomous regions). In Italy, there are regions with "ordinary" or "special" status. Eleven Member States have only one level of subnational authority (incl. Bulgaria), i.e., municipalities, nine others have two levels (municipalities and regions), and the remaining eight have three: municipalities, regions, and intermediate administrative-territorial units 
(e.g., departments, provinces, counties, etc.). It is important to give detailed information about the subnational levels of government for EU countries.

- Countries with one sub-national government level - Cyprus, Bulgaria, Estonia, Ireland, Latvia, Luxembourg, Malta, Finland, Portugal, Lithuania and Slovenia.

- Countries with two sub-national government level - Austria, Czech Republic, Denmark, Greece, Hungary, Netherlands, Romania, Slovakia, Croatia and Sweden.

- Countries with three sub-national government level - Belgium, France, Germany, Italy, Poland and Spain.

All three different groups are determined by the countries needs and their exact specification: like population and territory. In some cases, it is very important to have more than one governmental level as administration cannot be handled well with less involved institutions. In the first group we can compare Bulgaria and Portugal with similar territory and population and both with same administrative organization. The rest of the countries in this group are smaller and one subnational level is perfect fit for them. Second group with two subnational levels are bigger countries with higher number of citizens per province and they certainly need at least two levels of government. Decisions are taken on two different levels and this is decreasing the risks of abusive administration and corruption. In third group there are countries with separate state governance and this way we can even talk for different communities with their own laws and rules but under same flag.

The distribution of powers and the provision of public services in the EU seeks to fully reflect the principle of subsidiarity introduced by the Maastricht Treaty, according to which the principle of subsidiarity allows the intervention of the Union only when certain goals cannot be achieved at a lower (local or central level). Regarding the distribution of powers in the provision of public services Table №2 provides data for 19 countries. The information there allows us to review the organization and responsibilities of the different levels of government in providing basic public services. Given the various combinations in the power's distribution, it is possible that two or more competent authorities are responsible for a given service, so the total number in the different categories may be greater than 19 .

Table 2. Responsibilities in distribution of public services between levels of government [7]

\begin{tabular}{|c|c|c|c|c|c|c|c|c|c|c|c|}
\hline \multirow[b]{2}{*}{ Services } & \multicolumn{3}{|c|}{$\begin{array}{l}\text { Competent } \\
\text { authority }\end{array}$} & \multicolumn{4}{|c|}{ Type of power } & \multicolumn{4}{|c|}{ Executed by authority } \\
\hline & $\stackrel{2}{\mathscr{E}}$ & 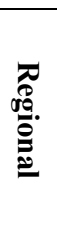 & 胥. & 可 & $\begin{array}{l}\mathscr{2} \\
\frac{2}{2} \\
2\end{array}$ & 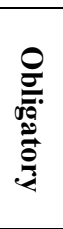 & 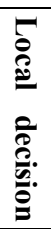 & $\begin{array}{l}= \\
\stackrel{7}{0} \\
\stackrel{0}{3}\end{array}$ & 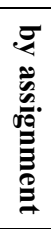 & 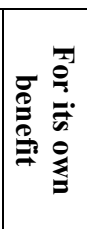 & 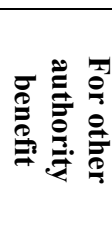 \\
\hline $\begin{array}{l}\text { Public order and } \\
\text { security }\end{array}$ & 19 & 6 & 12 & 15 & 5 & 19 & 6 & 19 & 0 & 12 & 8 \\
\hline Fire protection & 12 & 7 & 14 & 11 & 9 & 19 & 0 & 19 & 0 & 12 & 10 \\
\hline Civil Protection & 17 & 9 & 13 & 8 & 11 & 19 & 0 & 18 & 0 & 11 & 12 \\
\hline $\begin{array}{l}\text { Nurseries and } \\
\text { kindergartens }\end{array}$ & 3 & 2 & 18 & 14 & 5 & 11 & 9 & 18 & 4 & 13 & 2 \\
\hline Social institutions & 7 & 10 & 13 & 11 & 11 & 14 & 7 & 17 & 12 & 9 & 6 \\
\hline Housing policy & 7 & 5 & 19 & 14 & 5 & 3 & 15 & 16 & 13 & 14 & 2 \\
\hline $\begin{array}{l}\text { Water and } \\
\text { sanitation }\end{array}$ & 5 & 6 & 18 & 13 & 6 & 15 & 2 & 17 & 13 & 13 & 4 \\
\hline Cleanliness & 2 & 3 & 19 & 17 & 3 & 14 & 3 & 17 & 12 & 12 & 3 \\
\hline
\end{tabular}




\begin{tabular}{|c|c|c|c|c|c|c|c|c|c|c|c|}
\hline Landscaping & 10 & 10 & 19 & 14 & 6 & 4 & 13 & 17 & 14 & 16 & 1 \\
\hline $\begin{array}{c}\text { Street network } \\
\text { maintenance }\end{array}$ & 9 & 10 & 19 & 11 & 9 & 15 & 2 & 18 & 11 & 15 & 3 \\
\hline Public transport & 2 & 6 & 19 & 16 & 5 & 5 & 12 & 16 & 14 & 17 & 2 \\
\hline Gasification & 10 & 5 & 11 & 15 & 4 & 4 & 13 & 16 & 14 & 11 & 7 \\
\hline Central heating & 1 & 5 & 15 & 16 & 3 & 2 & 16 & 17 & 13 & 15 & 6 \\
\hline
\end{tabular}

\section{Conclusion}

The analysis of public service powers in most EU countries is summarized in the following conclusions:

- Regardless of the structure of the country and the number of sub-national levels of government, the services concerning the security of the citizens are always in the competences of the central government (or shared, but the central government is always involved);

- Public services contributing to convenience and a more rational way of life are usually provided either alone by local authorities or jointly with another level of government;

- Usually, the authority providing the given public service has full powers for its activity. For some services, such as "Civil Protection", "Street Network Maintenance" and others. there is shared responsibility between the authorities;

- The fully empowered level of government provides security services directly to citizens;

- Services such as public transport, garbage collection and others, for which quality is of great importance in delivery, are often subcontracted;

- All the countries concerned have been empowered to provide a large part of public services at the lowest level of self - government.

\section{References}

1. G. Benson, Level of Government at which Public Functions are Performed, in Federal expenditure policy for economic growth and stability, printed for the use of the Joint Economic Committee, United States Government Printing Office, Washington, 163173 (1957)

2. E. Mutafov, TJS, 11(1), 155-160 (2013)

3. E. W. Oates, Fiscal Federalism, New York: Harcourt Brace Jovanovich, 32 - 35 (1972)

4. S. Ivanov, Financial decentralization in the interest of local communities, Journal Public administration, 2 (2006)

5. G. Stigler, The Tenable Range of Functions of Local Government, in Federal expenditure policy for economic growth and stability, printed for the use of the Joint Economic Committee, (United States Government Printing Office, Washington, 213 220, 1957)

6. Ministry of regional development and public works, Strategy for decentralization of Republic of Bulgaria 2016-2025, https://www.mrrb.bg/static/media/ups/articles/attachments/42e3960042715c84ef700aa a6af00cc6.pdf

7. Subnational public finance in the European Union, 11th edition, 11 - 15 (2011)

8. V. Ostrom, E. Ostrom, Public Goods and Public Choices, (Imprint Routledge, 1977) 